\title{
Cytotoxic role of advanced glycation end-products in PC12 cells treated with $\beta$-amyloid peptide
}

\author{
FU-LING YAN, GUO-LING HAN and GUAN-JIN WU
}

Department of Neurology, Zhongda Hospital of Southeast University, Nanjing, Jiangsu 210009, P.R. China

Received January 18, 2013; Accepted May 17, 2013

DOI: $10.3892 / \mathrm{mmr} .2013 .1545$

\begin{abstract}
Alzheimer's disease (AD) is the most common type of dementia afflicting the elderly. Recent studies have increasingly suggested that a high concentration of advanced glycation end products (AGEs) may be important in AD pathogenesis. However, the mechanisms and pathways involved remain unknown. The aim of this study was to explore whether the mechanism of the effect of AGEs on $\mathrm{A} \beta$-PC12 cells [PC12 cells treated with $\beta$-amyloid $(\mathrm{A} \beta)$ peptide] was associated with oxidative stress; and to study whether inhibiting the activity of the receptor for AGE (RAGE) attenuated the toxic effect of AGEs and A $\beta$ on PC12 cells. Several PC12 cells were pretreated with A $\beta$, and were then treated with different concentrations of AGEs. Other PC12 cells were treated with trypsin, a pancreatic protein enzyme and an inhibitor of RAGE, and were then treated with $A \beta$ and AGEs. Apoptosis was measured by flow cytometry (FCM) and cell viability was measured by MTT assay. RAGE and nuclear factor $-\kappa \mathrm{B}(\mathrm{NF}-\kappa \mathrm{B})$ were measured by reverse transcription-polymerase chain reaction (RT-PCR) assay. With an increase in AGE concentration, the viability of A $\beta$-PC12 cells treated with AGEs decreased. However, the $\mathrm{A} \beta$-PC12 cell viability was greater in the trypsin group than in the non-trypsin group. Cell apoptosis rates and mRNA expression of RAGE and $\mathrm{NF}-\kappa \mathrm{B}$ in $\mathrm{A} \beta-\mathrm{PC} 12$ cells treated with AGEs were significantly higher than in the $\mathrm{A} \beta-\mathrm{PC} 12$ cells. AGEs and A $\beta$ were neurotoxic, and RAGE triggered the neural cytotoxic role of AGEs in A $\beta$-PC12 cells. The molecular mechanisms may be connected with the expression of $\mathrm{NF}-\kappa \mathrm{B}$ and apoptosis mediated by RAGE. Inhibiting the activity of RAGE may mitigate the toxic effect of AGEs and $A \beta$ on neural cells.
\end{abstract}

Correspondence to: Dr Fu-Ling Yan, Department of Neurology, Zhongda Hospital of Southeast University, 87 Dingjiaqiao, Nanjing, Jiangsu 210009, P.R. China

E-mail: yanfuling218@163.com

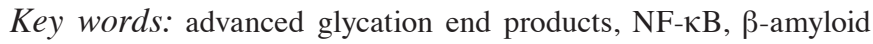
peptide, cell culture

\section{Introduction}

Alzheimer's disease (AD) is one of the most common diseases among the elderly. AD is the primary cause of dementia in old age (1). Over the last two decades, several hypotheses have been proposed to explain AD pathogenesis. One such hypothesis is the amyloid hypothesis, which states that $\beta$-amyloid $(\mathrm{A} \beta)$ peptide deposits are the fundamental cause of the disease (2).

The accumulation of $A \beta$ in cerebral senile plaques is a major pathological hallmark of AD. Therefore, $A \beta$ peptides are central to the pathogenesis of AD. Despite the genetic and cell biological evidence that supports the amyloid hypothesis, it is becoming increasingly clear that AD etiology is complex, and that $\mathrm{A} \beta$ alone is unable to account for all aspects of $\mathrm{AD}$. In 2000, evidence strongly suggested that advanced glycation end products (AGEs) have an important toxic role in $\mathrm{AD}$ pathogenesis (3). In vitro experiments demonstrated that AGEs and $A \beta$ are co-localized in the core of senile plaques, and that they are able to attract and cause the aggregation of soluble $\mathrm{A} \beta$.

$\mathrm{A} \beta$ is a pleiotropic peptide and is capable of binding to receptors at several different membrane locations (4). The receptor for AGEs (RAGE), a multi-ligand receptor of the immunoglobulin superfamily of cell surface molecules (5), possesses a cell surface binding site for $A \beta$ peptides (4) and is expressed at higher levels when stimulated by excessive levels of $\mathrm{A} \beta$ (6). RAGE has been extensively studied for its roles in the migration and differentiation of neuronal cells during development, the perturbation of neuronal cells by $A \beta$ and the inflammatory response $(3,7)$.

Induced expression of RAGE is frequently correlated with pathological stages such as diabetic endothelial damage and $\mathrm{AD}(8,9)$. It has been proposed that RAGE is responsible for $\mathrm{A} \beta$ neurotoxicity (10). However, the mechanism whereby RAGE is able to recognize AGEs and A $\beta$, if these molecules are not glycated, remains unclear. Studies have suggested that AGEs are inducers of chronic inflammation and acute-phase responses in a variety of diseases $(4,11)$. However, this hypothesis is not clear in the brains of patients with AD.

In the present study, we aimed to observe the effects of AGEs on PC12 cells pretreated with A $\beta 25-35$, to explore whether the mechanism of action is associated with oxidative stress, and to study whether inhibiting the activity of RAGE attenuates the toxic effect of AGEs. 


\section{Materials and methods}

Production of AGEs and fibrillar A $\beta$. AGEs were produced by incubation of $1 \mathrm{mM}$ bovine serum albumin (BSA; Roce, Indianapolis, IN, USA) with $1 \mathrm{M}$ glucose at $50^{\circ} \mathrm{C}$ in phosphate-buffered saline (PBS) at $\mathrm{pH} 7.4$ for 60 days. Samples were initially filtered through a $0.2-\mu \mathrm{m}$ filter and kept sterile during the incubations. A slightly elevated temperature was used to accelerate the reaction and avoid bacterial contamination. Unbound sugars were removed through extensive dialysis using distilled water. AGEs were lyophilized and resuspended in PBS. The controlled BSA was incubated under the same conditions, except that glucose was omitted. AGE purity was assessed with fluorometry and chromatographic analysis exploiting the selective fluorescence of AGEs at an optical density of $400 \mathrm{~nm}$ (the excitation wavelength was $370 \mathrm{~nm}$ ) (12). Fibrillar A $325-35$ (13) was produced by incubating the peptide $(1 \mathrm{mM})$ in $10 \mathrm{mM}$ PBS under sterile conditions for 7 days at $37^{\circ} \mathrm{C}$.

Cell culture. PC-12 cells (ATCC, Manassas, VA, USA) were seeded into 96-well flat bottom tissue culture plates (Corning, USA) at a density of $3 \times 10^{5}$ cells $/ \mathrm{ml}$ for the MTT assay, and into 24-well plates at a density of $6 \times 10^{5}$ cells $/ \mathrm{ml}$ for the remaining assays. Cells were grown in Dulbecco's Modified Eagle's Medium (DMEM; Life Technologies, Carlsbad, CA, USA) supplemented with $10 \%$ fetal calf serum, streptomycin and penicillin $(100 \mathrm{mg} / \mathrm{ml}$ and $100 \mathrm{U} / \mathrm{ml})$, and $2 \mathrm{mM} \mathrm{L}$-glutamine at $37^{\circ} \mathrm{C}$ in a humidified atmosphere containing $5 \% \mathrm{CO}_{2}$ and $95 \%$ air.

Grouping. A $\beta-\mathrm{PC} 12$ cells were $\mathrm{PC}-12$ cells pretreated with $\mathrm{A} \beta 25-35$. A $\beta-\mathrm{PC} 12$ cells were treated with different levels of AGEs. PC-12 cells were divided into five groups: i) the control group: PC12 cells were cultured with $12.5 \mu 1$ of $30 \% \mathrm{BSA}$; ii) the $\mathrm{A} \beta$ group: $\mathrm{PC} 12$ cells were cultured with $25 \mu \mathrm{mol} / 1$ $\mathrm{A} \beta 25-35$, and termed $\mathrm{A} \beta-\mathrm{PC} 12$ cells; iii) the $\mathrm{A} \beta+\mathrm{L}-\mathrm{AGE}$ group: $\mathrm{A} \beta-\mathrm{PC} 12$ cells were cultured with a low volume of AGEs $(12.5 \mu \mathrm{l})$; iv) the $\mathrm{A} \beta+\mathrm{M}-\mathrm{AGE}$ group: $\mathrm{A} \beta-\mathrm{PC} 12$ cells were cultured with a medium volume of AGEs $(25 \mu \mathrm{l})$; and v) the $\mathrm{A} \beta+\mathrm{H}-\mathrm{AGE}$ group: $\mathrm{A} \beta-\mathrm{PC} 12$ cells were cultured with a high volume of AGEs $(50 \mu \mathrm{l})$.

RAGE was inhibited by trypsin (14) to determine whether RAGE was involved in AGE and A $\beta$ toxicity. In the trypsin group, $\mathrm{PC} 12$ cells were pretreated with $1 \mathrm{mg} / \mathrm{ml}$ trypsin at $37^{\circ} \mathrm{C}$ for $30 \mathrm{~min}$, and washed three times with PBS. Subsequently, $25 \mu \mathrm{mol} / 1 \mathrm{~A} \beta 25-35$ was added and cells were incubated at $37^{\circ} \mathrm{C}$ for $24 \mathrm{~h}$, before the addition of $50 \mu \mathrm{l}$ AGE. In the non-trypsin group, PC12 cells were not pretreated with trypsin (Gibco, USA); however, $25 \mu \mathrm{mol} / 1 \mathrm{~A} \beta 25-35$ was directly added and the cells were incubated at $37^{\circ} \mathrm{C}$ for $24 \mathrm{~h}$, which was followed by the addition of $50 \mu \mathrm{l}$ AGE.

MTT assay. Following incubation of the cells with AGEs and $\mathrm{A} \beta$, the medium was removed and the cells were washed with PBS. Subsequently, $100 \mathrm{ml}$ DMEM, without phenol red, and $25 \mathrm{ml}$ of an MTT solution $(1.5 \mathrm{mg} / \mathrm{ml}$ in PBS) were added to each well, followed by incubation for $4 \mathrm{~h}$. The MTT solution was carefully removed from the wells to avoid the loss of formazan crystals before they were dissolved with $100 \mathrm{ml}$ dimethyl sulfoxide/ethanol (1:1). Absorbance was measured at $550 \mathrm{~nm}$ with the reference filter set to $630 \mathrm{~nm}$. MTT assays were performed in triplicate for each experiment.

Reverse transcription-polymerase chain reaction (RT-PCR). $\mathrm{PC}-12$ cells were grown under the same conditions as described previously. Following removal of the medium, cells were washed with PBS and lysed with $1 \mathrm{ml}$ TRIzol (Takara, Japan) for $5 \mathrm{~min}$. Following centrifugation at $12,000 \mathrm{xg}$ at $4^{\circ} \mathrm{C}$ for $10 \mathrm{~min}$, the supernatant was mixed with $200 \mu 1$ chloroform and shaken for $30 \mathrm{sec}$. Subsequently, $400 \mu \mathrm{l}$ isopropanol was added to the aqueous phase, and the mixture was allowed to stand for $10 \mathrm{~min}$. Following centrifugation at $12,000 \mathrm{x}$ g at $4^{\circ} \mathrm{C}$ for $10 \mathrm{~min}$, the obtained pellet was rinsed with $75 \%$ ethanol, dried and then dissolved in diethyl pyrocarbonate-treated water. Further RNA purification was performed using the Qiagen RNeasy kit, according to the manufacturer's instructions (Qiagen, Germany). The Stratagene RT-PCR kit was used for reverse transcription of total RNA (Table I).

The PCR procedure was implemented as follows: RAGE: 1 cycle at $95^{\circ} \mathrm{C}$ for $4 \mathrm{~min} ; 35$ cycles at $95^{\circ} \mathrm{C}$ for $50 \mathrm{sec}, 58^{\circ} \mathrm{C}$ for $50 \mathrm{sec}$ and $72^{\circ} \mathrm{C}$ for $1 \mathrm{~min}$; and 1 cycle at $72^{\circ} \mathrm{C}$ for $7 \mathrm{~min}$; and nuclear factor- $\mathrm{\kappa B}(\mathrm{NF}-\kappa \mathrm{B}): 1$ cycle at $95^{\circ} \mathrm{C}$ for $1 \mathrm{~min} ; 35$ cycles at $95^{\circ} \mathrm{C}$ for $30 \mathrm{sec}, 60^{\circ} \mathrm{C}$ for $30 \mathrm{sec}$ and $68^{\circ} \mathrm{C}$ for $2 \mathrm{~min}$; and 1 cycle at $65^{\circ} \mathrm{C}$ for $10 \mathrm{~min}$.

PCR products were loaded and run on a $1.8 \%$ agarose gel and visualized following ethidium bromide staining using a UV transilluminator.

Apoptosis rate and flow cytometry (FCM) analysis. PC12 cells were harvested by centrifugation at $12,000 \mathrm{x}$ g for $5 \mathrm{~min}$ and then washed twice with cold PBS, before being resuspended in $100 \mu \mathrm{l}$ binding buffer with $\sim 10^{6}$ cells. Subsequently, $5 \mu \mathrm{l}$ fluorescein isothiocyanate (FITC)-annexin $\mathrm{V}$ and $5 \mu \mathrm{l}$ propidium iodide (PI) were added. Cells were gently oscillated and incubated in the dark for $15 \mathrm{~min}$ at $25^{\circ} \mathrm{C}$. Following the addition of $400 \mu \mathrm{l}$ binding buffer to each tube, the cells were analyzed by FCM within $1 \mathrm{~h}$. Cells that stained positive for FITC-annexin V and negative for PI were considered to be in apoptosis. Cells that stained positive for FITC-annexin V and PI were considered to either be in necrosis or dead. Cells that stained negative for FITC-annexin $\mathrm{V}$ and PI were considered to be living. The FACSCalibur flow cytometer (BD Biosciences, Franklin Lakes, NJ, USA) was used to conduct the FCM. Data were analyzed using CellQuest software and the apoptosis rates were provided.

Statistical analysis. Statistical analysis of the results was carried out by analysis of variance (ANOVA) using the Statistical Package for the Social Sciences (SPSS; SPSS, Inc., Chicago, IL, USA). Either the Student's t-test or the Wilcoxon rank sum test were used, depending on the normality of the data distribution. $\mathrm{P}<0.05$ was considered to indicate a statistically significant result.

\section{Results}

Cell viability. The influence of $\mathrm{A} \beta$ and the different concentrations of AGEs on the viability of PC12 cells is presented in Table II. Optical density (OD) values were determined by MTT 
Table I. Primers used in this study.

\begin{tabular}{llc}
\hline \multicolumn{1}{l}{ Type } & Primer sets & Length (bp) \\
\hline RAGE & 5'-AGACCAAGTCCAACTACCGAG-3' & 408 \\
& 5'-CCTTCACAGATACTCCCTTCAT-3' & 198 \\
NF- $\mathrm{sB}$ & 5'-AGCACAGATACCACCAAGACCC-3' & 260 \\
& 5'-CCCACGCTGCTCTTCTATAGGAAC-3' & 5'-CAATTCCATCATGAAGTGTGAC-3' \\
& 5'-CCACACAGAGTACTTGCGCTC-3' \\
\hline
\end{tabular}

RAGE, receptor for advanced glycation end products; NF- $\mathrm{kB}$, nuclear factor- $\mathrm{\kappa B}$.

Table II. Changes in cell viability following incubation with $\mathrm{A} \beta$ and AGEs.

\begin{tabular}{lcc}
\hline Group & \multicolumn{1}{c}{ OD } & Viability (\%) \\
\hline Control & $0.8109 \pm 0.1826$ & 100.00 \\
$\mathrm{~A} \beta$ & $0.5847 \pm 0.1044^{\mathrm{a}}$ & 72.11 \\
$\mathrm{~A} \beta+\mathrm{L}-\mathrm{AGE}$ & $0.3876 \pm 0.0781^{\mathrm{a}, \mathrm{b}}$ & 47.80 \\
$\mathrm{~A} \beta+\mathrm{M}-\mathrm{AGE}$ & $0.2758 \pm 0.0593^{\mathrm{a}, \mathrm{b}}$ & 34.01 \\
$\mathrm{~A} \beta+\mathrm{H}-\mathrm{AGE}$ & $0.0969 \pm 0.0800^{\mathrm{a}, \mathrm{b}}$ & 11.95 \\
\hline
\end{tabular}

${ }^{\mathrm{a}} \mathrm{P}<0.01$ vs. control group and ${ }^{\mathrm{b}} \mathrm{P}<0.01$ vs. $\mathrm{A} \beta$ group. $\mathrm{A} \beta, \beta$-amyloid; AGE, advanced glycation end product; OD, optical density; L, low; $\mathrm{M}$, medium; $\mathrm{H}$, high.

assay. The cell viability was calculated using the following formula: Cell viability $=\left(\mathrm{OD}_{\text {sample value }} / \mathrm{OD}_{\text {control value }} \times 100 \%\right.$. Statistical analysis indicated that cell viability in the $A \beta$ and $\mathrm{A} \beta+\mathrm{AGEs}$ groups was lower than that of the control group $(\mathrm{P}<0.01)$. The cell viability decreased in the three groups of the different volumes of AGEs compared with the $A \beta$ group $(\mathrm{P}<0.01)$. The effects of AGEs on $\mathrm{A} \beta-\mathrm{PC} 12$ cell viability were dose dependent. As demonstrated in Table III, the cell viability in the trypsin group was greater than that of the non-trypsin group $(\mathrm{P}<0.01)$.

$R T-P C R$. The expression of RAGE mRNA in the PC12 cells was at $408 \mathrm{bp}$ in all groups. The levels of RAGE mRNA in the $\mathrm{A} \beta+\mathrm{L}-\mathrm{AGE}, \mathrm{A} \beta+\mathrm{M}-\mathrm{AGE}$ and $\mathrm{A} \beta+\mathrm{H}-\mathrm{AGE}$ groups were higher than in the $A \beta$ group. The expression value of RAGE mRNA increased with increasing AGE concentration, as demonstrated in Table IV. The expression of NF- $\kappa \mathrm{B}$ mRNA in the PC12 cells was at $198 \mathrm{bp}$ in all groups. The levels of NF- $\mathrm{B}$ mRNA in the $\mathrm{A} \beta+\mathrm{L}-\mathrm{AGE}, \mathrm{A} \beta+\mathrm{M}-\mathrm{AGE}$ and $\mathrm{A} \beta+\mathrm{H}-\mathrm{AGE}$ groups were higher than in the $A \beta$ group. The expression value of $N F-\kappa B$ mRNA increased with increasing AGE concentration, as presented in Table IV.

Apoptosis rate. Apoptosis was induced by $\mathrm{A} \beta$ and the different concentrations of AGEs, and was quantified as the percentage of apoptotic cells. The rate of apoptosis was calculated using the following formula: Apoptosis rate $=$ (number of apoptotic cells/total number of cells) x $100 \%$. Apoptosis rates in all
Table III. Changes in cell viability following incubation with trypsin and AGEs.

\begin{tabular}{lcc}
\hline Group & OD & Viability (\%) \\
\hline No trypsin & $0.1103 \pm 0.0451$ & 13.01 \\
Trypsin & $0.4414 \pm 0.0357^{\mathrm{a}}$ & 52.05 \\
\hline
\end{tabular}

${ }^{\mathrm{a}} \mathrm{P}<0.01$ vs. the group without trypsin. AGE, advanced glycation end product; OD, optical density.

groups of $\mathrm{A} \beta-\mathrm{PC} 12$ cells $(16.06,24.57,36.89$ and $43.85 \%$ in the $\mathrm{A} \beta, \mathrm{A} \beta+\mathrm{L}-\mathrm{AGE}, \mathrm{A} \beta+\mathrm{M}-\mathrm{AGE}$ and $\mathrm{A} \beta+\mathrm{H}-\mathrm{AGE}$ groups, respectively) were higher than in PC12 cells $(2.01 \%$ in the control group; $\mathrm{P}<0.01)$. The cell apoptosis rate significantly increased in the $\mathrm{A} \beta+\mathrm{M}-\mathrm{AGE}$ and $\mathrm{A} \beta+\mathrm{H}-\mathrm{AGE}$ groups compared with the $A \beta$ group $(\mathrm{P}<0.01)$. In the $A \beta+A G E$ groups, the cell apoptosis rate increased with increasing AGE concentration, as demonstrated in Fig. 1.

\section{Discussion}

$\mathrm{AD}$ is a neurodegenerative disorder characterized by progressive degeneration and loss of neurons in the brain, which has been correlated with the appearance of senile plaques, the neuropathological hallmarks of $\mathrm{AD}$. As the major component of senile plaques, $A \beta$ is considered to play a key role in the development and progression of AD (15).

A potential mechanism for the effect of $A \beta$ is presented in Fig. 2. This mechanism accounts for the fact that the increasing concentrations of AGEs with age predispose to the injurious signal presented by $\mathrm{A} \beta$.

A $\beta$-PC12 cells, PC12 cells treated with A $\beta 25-35$, have been recognized as having the ability to mimic classical AD pathology, such as inhibited cell multiplication, induced cell metamorphosis, cell damage, functional loss and even cell death (12). In vitro studies have demonstrated that $\mathrm{A} \beta$ has nutritional value for cultured hippocampal neurons, as well as being toxic to these cells. The role that $A \beta$ assumes depends on two factors, which include the maturity of neurons and the concentration of $\mathrm{A} \beta(14,16)$. A high concentration of $\mathrm{A} \beta$ triggers the toxic property, causing a loss of mature neurons and inhibition of axon growth. The working domain of $\mathrm{A} \beta$ has been confirmed 
Table IV. Expression of RAGE mRNA and NF- $\kappa$ B mRNA in PC-12 cells.

\begin{tabular}{|c|c|c|c|c|c|c|}
\hline Group & RAGE & $\beta$-Actin & RAGE $/ \beta$-actin & $N F-\kappa B$ & $\beta$-Actin & $N F-\kappa B / \beta$-actin \\
\hline $\mathrm{A} \beta$ & $113.27 \pm 4.16$ & $290.83 \pm 8.47$ & $38.94 \pm 0.60$ & $121.20 \pm 8.21$ & $278.80 \pm 15.33$ & $43.47 \pm 5.02$ \\
\hline $\mathrm{A} \beta+\mathrm{L}-\mathrm{AGE}$ & $178.63 \pm 10.05$ & $318.93 \pm 5.65$ & $56.01 \pm 4.15^{\mathrm{a}}$ & $176.90 \pm 2.69$ & $311.07 \pm 6.89$ & $56.87 \pm 1.08^{a}$ \\
\hline $\mathrm{A} \beta+\mathrm{M}-\mathrm{AGE}$ & $308.80 \pm 7.89$ & $362.60 \pm 12.11$ & $85.16 \pm 2.11^{\mathrm{a}, \mathrm{b}}$ & $265.83 \pm 13.01$ & $354.20 \pm 4.83$ & $75.05 \pm 3.31^{\mathrm{a}}$ \\
\hline $\mathrm{A} \beta+\mathrm{H}-\mathrm{AGE}$ & $347.67 \pm 5.67$ & $373.77 \pm 20.69$ & $93.02 \pm 5.09^{\mathrm{a}, \mathrm{b}}$ & $316.87 \pm 10.05$ & $371.17 \pm 10.18$ & $85.37 \pm 6.63^{\mathrm{a}, \mathrm{b}}$ \\
\hline
\end{tabular}

${ }^{\mathrm{a}} \mathrm{P}<0.01$ vs. $\mathrm{A} \beta$ group and ${ }^{\mathrm{b}} \mathrm{P}<0.01$ vs. $\mathrm{A} \beta+\mathrm{L}-\mathrm{AGE}$ group. RAGE, receptor for advanced glycation end products; NF- $\mathrm{kB}$, nuclear factor- $\mathrm{kB} ; \mathrm{A} \beta$, $\beta$-amyloid; L, low; M, medium; H, high.

A

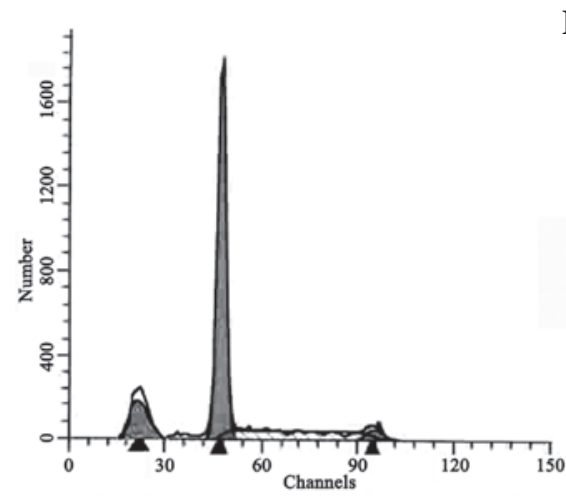

C

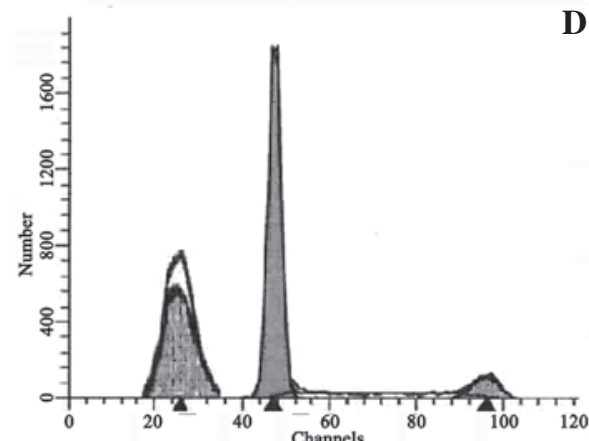

$\mathbf{E}$

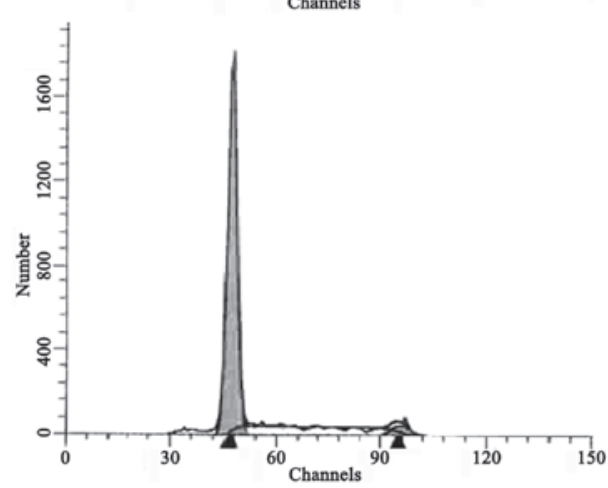

B

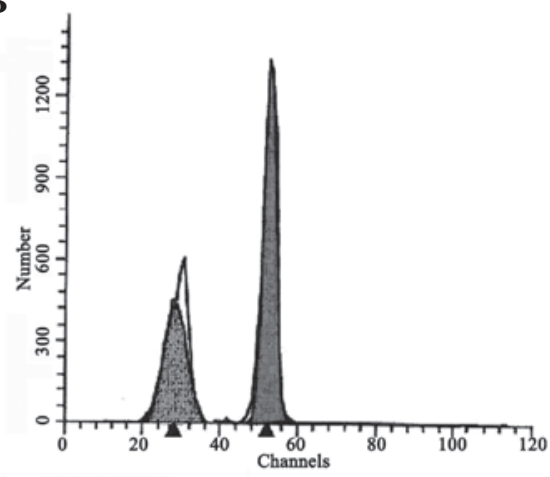

D

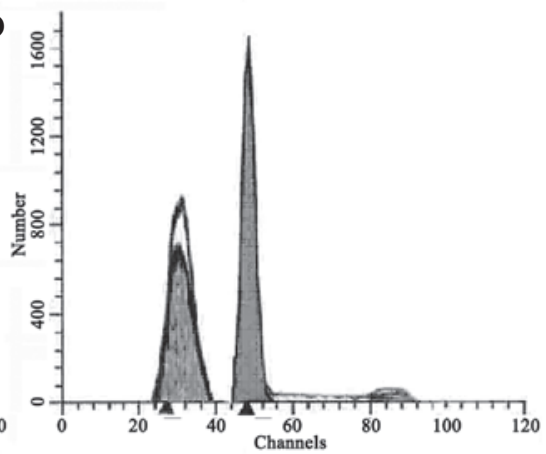

Figure 1. Apoptosis of PC12 cells.

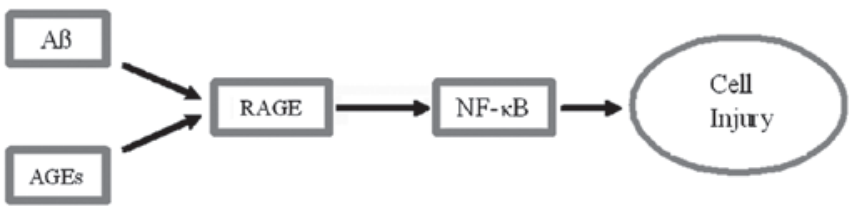

Figure 2. Potential mechanism for the effect of $\beta$-amyloid (A $\beta)$. AGE, advanced glycation end product; RAGE, receptor for AGE; NF- $\mathrm{kB}$, nuclear factor- $\mathrm{\kappa} \mathrm{B}$. to be the amino acid residues in 25-35 sites. In the present study, A $\beta 25-35$ was added to PC12 cells as a neurotoxin. This addition inhibited PC12 cell multiplication and induced cell death, which was consistent with previous studies $(12,17)$.

AGEs are important agents in the proposed mechanism of $\mathrm{A} \beta$-mediated cell injury in AD. AGEs are a series of irreversible polymers produced by the Maillard reaction, a non-enzymatic glycation and oxidation reaction between carbohydrate-derived 
carbonyl compounds and the free $\mathrm{N}$-terminal of proteins forming brown fluorescent reaction end products (18). As these products auto-fluoresce, we can use the fluorescence chromatogram to identify them at an excitation wavelength of 350-399 $\mathrm{nm}$ and an emission wavelength of 440-470 nm.

RAGE is a 404-amino acid protein, which belongs to a family of cell surface molecules with immunoglobulin folds. RAGE is expressed in endothelial cells, mononuclear phagocytes (monocytes, macrophages and mesangial cells), neurons and muscle cells. The protein is expressed at a high level in the nervous system during development. Induced expression is frequently associated with pathological stages, such as diabetic endothelial damage and AD $(8,9,19)$.

Proteins modified by AGEs may lose their normal functions. Studies have proposed that AGEs transmit their cell toxicity signals through RAGE. When AGEs are combined with RAGE, located at the cytomembrane of macrophages, these proteins may be degraded and cleared. Thus, the modification of proteins by AGEs is considered to be a signal participating in the procedure of rebuilding and clearing aging tissues. The production of AGEs is enhanced due to the glycometabolic disorder in patients with AD, while the clearance of AGEs is inhibited.

AGE formation is normally slow. In humans, AGEs normally accumulate with increasing age. In AD, AGEs accumulate on $\beta$-amyloid plaques near microglia and astrocytes. $\mathrm{A} \beta$, derived by proteolytic cleavage of the amyloid precursor protein, is the major protein component of senile plaques. In vitro experiments have demonstrated that $\mathrm{AGEs}$ and $\mathrm{A} \beta$, co-localized in the core of senile plaques, attract additional A $\beta$ to form aggregates (20). Several studies have proposed that once AGEs have accumulated on $\beta$-amyloid plaques in the brains of patients with $\mathrm{AD}$, they may aggravate $\mathrm{A} \beta$-mediated oxidative stress, cell damage, functional loss and even neuronal cell death in the AD brain via RAGE-dependent mechanisms.

Several different theories have been proposed for the initial interaction between $A \beta$ and the cell, as $A \beta$ has a direct toxic effect on neuronal cells. RAGE has been demonstrated to be responsible for $A \beta$ neurotoxicity (10). However, the mechanism whereby RAGE is able recognize AGEs, if these synthetic peptides are not glycated, remains unclear. In the present study, different concentrations of AGEs were added to cultures of $\mathrm{A} \beta$-PC12 cells to determine whether RAGE was involved in $A \beta$ toxicity. High concentrations of AGEs accelerated the $\mathrm{A} \beta$ toxicity in PC12 cells. The toxicity of AGEs and A $\beta$ was decreased when the RAGE of the cultured cell was inactivated by treatment with trypsin. Glycated albumin bound to RAGE on the cell activated the $A \beta$ toxic response and increased the toxicity induced by $A \beta$ in neural cells. Inactivating RAGE may block neurocytotoxicity induced by A $\beta$. RAGE mRNA was detected by PCR analysis when AGEs were added to cultures of A $\beta$-PC1 2 cells. These results strongly suggested that RAGE was involved in mediating the toxic effect of AGEs and $A \beta$ on nerve cells.

AGEs have been suggested to be inducers of chronic inflammation and acute-phase responses in a variety of diseases $(4,11)$. However, this is not clear in brains of patients with AD. Recent studies have determined that microglia activated by AGEs are co-localized with AGE-modified $\beta$-amyloid plaques $(21,22)$. The present study and previous studies have demonstrated that
AGEs activate NF- $\kappa \mathrm{B}$ and upregulate NF- $\kappa \mathrm{B}$ mRNA expression in $\mathrm{A} \beta-\mathrm{PC} 12$ cells, and that $\mathrm{NF}-\kappa \mathrm{B}$ mRNA expression increased with an elevation in AGE concentration.

Binding of $A \beta$ to RAGE on neurons may cause cellular perturbation due to the induction of oxidative stress and the activation of the transcription factor, $N F-\kappa B$. One of the consequences of this interaction is the production of microglia/macrophage growth factor and macrophage colony-stimulating factor (M-CSF) (23). The promoter of the RAGE gene contains two functional NF- $\kappa \mathrm{B}$ binding sites, which provide a mechanism whereby RAGE activation by $A \beta$ results in increased expression of the RAGE gene. Furthermore, RAGE-dependent $\mathrm{NF}-\kappa \mathrm{B}$ activation by $\mathrm{A} \beta$ has other pro-inflammatory effects. For example, RAGE-A $\beta$ interactions lead to increased TNF- $\alpha$ secretion, and increased M-CSF and vascular cell adhesion molecule expression by neuroblastoma cells. Other RAGE ligands have also been determined to induce $\mathrm{NF}-\kappa \mathrm{B}$ activation and contribute to inflammatory responses (24).

In the present study, we inferred that an internal cycle between $\mathrm{A} \beta$, AGEs, oxidative stress and NF- $\mathrm{NB}$ exists; and that this cycle may form a morbigenous network in $\mathrm{AD}$ pathogenesis. In our findings, $A \beta$ cooperated with AGEs, resulting in concentration-dependent expression of $\mathrm{NF}-\kappa \mathrm{B}$. However, the effects of AGEs and $A \beta$ were no longer evident if RAGE was blocked by trypsin. This indicated that one of the pathways of cytotoxicity caused by $\mathrm{A} \beta$ was dependent on RAGE on the surface of neurons and glial cells for stimulating the release of reactive oxygen species (ROS), as well as the expression of $\mathrm{NF}-\kappa \mathrm{B}$ and the series of subsequent pathological processes.

$\mathrm{A} \beta$ may be involved in the etiology of $\mathrm{AD}$ through oxidative stress. A $\beta$ generates free radicals in a metal-catalyzed reaction, which is able to induce neuronal cell death by a ROS-mediated process, and is able to damage neuronal membrane lipids, proteins and nucleic acids. Several studies have demonstrated that necrotic and apoptotic mechanisms are implicated in $A \beta$-mediated neurotoxicity (25). Apoptosis is induced by micromolar concentrations of $A \beta$ in cultured neurons $(26,27)$. Our experiment demonstrated that the rate of PC12 cell apoptosis was higher in the A $\beta+A G E s$ groups than in the $A \beta$ group, and that the apoptosis rate increased with increasing AGE concentration. Additionally, RAGE may be involved in the pathogenesis of AD cells as one of the surface receptors mediating apoptosis. Further research is required to clarify this mechanism.

\section{References}

1. Jellinger KA and Attems J: Prevalence of dementia disorders in the oldest-old: an autopsy study. Acta Neuropathol 119: 421-433, 2010.

2. Tam JH and Pasternak SH: Amyloid and Alzheimer's disease: inside and out. Can J Neurol Sci 39: 286-298, 2012.

3. Schmidt AM, Yan SD, Yan SF and Stern DM: The biology of the receptor for advanced glycation end products and its ligands. Biochim Biophys Acta 1498: 99-111, 2000.

4. Yan SD, Chen X, Fu J, et al: RAGE and amyloid-beta peptide neurotoxicity in Alzheimer's disease. Nature 382: 685-691, 1996.

5. Bartus RT and Dean RL 3rd: Pharmaceutical treatment for cognitive deficits in Alzheimer's disease and other neurodegenerative conditions: exploring new territory using traditional tools and established maps. Psychopharmacology (Berl) 202: 15-36, 2009. 
6. Lue LF, Walker DG, Brachova L, et al: Involvement of microglial receptor for advanced glycation endproducts (RAGE) in Alzheimer's disease: identification of a cellular activation mechanism. Exp Neurol 171: 29-45, 2001

7. Yan SD, Bierhaus A, Nawroth PP and Stern DM: RAGE and Alzheimer's disease: a progressionfactor for amyloid-beta-induced cellular perturbation? J Alzheimers Dis 16: 833-843, 2009.

8. Yamagishi S: Role of advanced glycation end products (AGEs) and receptor for AGEs (RAGE) in vascular damage in diabetes. Exp Gerontol 46: 217-224, 2011.

9. Srikanth V, Maczurek A, Phan T, et al: Advanced glycation endproducts and their receptor RAGE in Alzheimer's disease. Neurobiol Aging 32: 763-777, 2011.

10. Kojro E and Postina R: Regulated proteolysis of RAGE and AbetaPP as possible link between type 2 diabetes mellitus and Alzheimer's disease. J Alzheimers Dis 16: 865-878, 2009.

11. Schwedler S, Schinzel R, Vaith P and Wanner C: Inflammation and advanced glycation end products in uremia: simple coexistence, potentiation or causal relationship? Kidney Int Suppl 78: S32-S36, 2001.

12. Pike CJ, Burdick D, Walencewicz AJ, Glabe CG and Cotman CW: Neurodegeneration induced by beta-amyloid peptides in vitro: the role of peptide assembly state. J Neurosci 13: 1676-1687, 1993.

13. Makita Z, Vlassara H, Cerami A and Bucala R: Immunochemical detection of advanced glycosylation end products in vivo. J Biol Chem 267: 5133-5138, 1992.

14. Weldon DT, Maggio JE and Mantyh PW: New insights into the neuropathology and cell biology of Alzheimer's disease. Geriatrics 52 (Suppl 2): S13-S16, 1997.

15. Maczurek A, Shanmugam K and Münch G: Inflammation and the redox-sensitive AGE-RAGE pathway as a therapeutic target in Alzheimer's disease. Ann NY Acad Sci 1126: 147-151, 2008.

16. Perrone L, Sbai O, Nawroth PP and Bierhaus A: The complexity of sporadic Alzheimer's disease pathogenesis: the role of RAGE as therapeutic target to promote neuroprotection by inhibiting neurovascular dysfunction. Int J Alzheimers Dis 2012: 734956, 2012.

17. Mucke L and Selkoe DJ: Neurotoxicity of Amyloid $\beta$-Protein: Synaptic and Network Dysfunction. Cold Spring Harb Perspect Med 2: a006338, 2012.
18. Visentin S, Medana C, Barge A, Giancotti V and Cravotto G: Microwave-assisted Maillard reactions for the preparation of advanced glycation end products (AGEs). Org Biomol Chem 8: 2473-2477, 2010

19. Li JJ, Dickson D, Hof PR and Vlassara H: Receptors for advanced glycosylation endproducts in human brain: role in brain homeostasis. Mol Med 4: 46-60, 1998

20. Cuevas E, Lantz SM, Tobón-Velasco JC, et al: On the in vivo early toxic properties of A-beta 25-35 peptide in the rat hippocampus: involvement of the Receptor-for-Advanced Glycation-End-Products and changes in gene expression. Neurotoxicol Teratol 33: 288-296, 2011.

21. Wilkinson K and El Khoury J: Microglial scavenger receptors and their roles in the pathogenesis of Alzheimer's disease. Int J Alzheimers Dis 2012: 489456, 2012.

22. Lue LF, Kuo YM, Beach T and Walker DG: Microglia activation and anti-inflammatory regulation in Alzheimer's disease. Mol Neurobiol 41: 115-128, 2010.

23. Llano DA, Li J, Waring JF, et al: Cerebrospinal fluid cytokine dynamics differ between Alzheimer disease patients and elderly controls. Alzheimer Dis Assoc Disord 26: 322-328, 2012.

24. Zhu C, Xiong Z, Chen X, et al: Artemisinin attenuates lipopolysaccharide-stimulated proinflammatory responses by inhibiting NF-кB pathway in microglia cells. PLoS One 7: e35125, 2012.

25. Fang F, Lue LF, Yan S, et al: RAGE-dependent signaling in microglia contributes to neuroinflammation, Abeta accumulation, and impaired learning/memory in a mouse model of Alzheimer's disease. FASEB J 24: 1043-1055, 2010.

26. Neniskyte U, Neher JJ and Brown GC: Neuronal death induced by nanomolar amyloid $\beta$ is mediated by primary phagocytosis of neurons by microglia. J Biol Chem 286: 39904-39913, 2011.

27. Cai Z, Zhao B and Ratka A: Oxidative stress and $\beta$-amyloid protein in Alzheimer's disease. Neuromolecular Med 13: 223-250, 2011. 